Special issue of the International Conference on Computational and Experimental Science and Engineering (ICCESEN 2014)

\title{
Soil Stabilization with Using Waste Materials against Freezing Thawing Effect
}

\author{
F. YILmAZ ${ }^{a, *}$, H.A. KAMILOĞLU ${ }^{a}$ AND E. ŞADOĞLU ${ }^{b}$ \\ ${ }^{a}$ Bayburt University/Civil Engineering Department, Bayburt, Turkey \\ ${ }^{b}$ Karadeniz Technical University, Civil Engineering Department, Trabzon, Turkey
}

\begin{abstract}
Freezing-thawing processes hapenning in seasonally cold climate cause deformation of soil in time of freezing and strength loss while thawing. Problems of ground frost heave and soil softening belong to the important factors, that could cause serious damage and financial loss. Bayburt tuff and tuffites known as Bayburt Stone mines, located around Bayburt, play important role on economy of the Bayburt city. As a result of researches in 2005 total of 2535700 tons proved reserve were determined several places in Bayburt. The goal of this study is proving, that deposits of Green Bayburt Stone wastes, created in the stone quarries during the stone processing, can be used as a stabilizing material. By recycling the waste material rejected stone was mixed with lime and used as a soil stabilizator against freezing-thawing effect. Prepared natural and stabilized soil samples were subjected to freezing-thawing cycles after curing for 28 days. After the freezing-thawing cycles, compressive strength of the samples was measured to investigate the influence of the additives on the freezing-thawing properties of soil samples. As a result of this study, it was determined that samples stabilized with Green Bayburt Stone mixtures have high freezing-thawing durability as compared to unstabilized samples. As a consequence, it was seen that those mixtures can be successfully used as an additive material to enhance the freezing-thawing effects of cohessive soils.
\end{abstract}

DOI: 10.12693/APhysPolA.128.B-392

PACS: 89.60.Kk, 89.60.-k

\section{Introduction}

Improvement of physical, hydraulic, mechanical and chemical properties of poor soil is called soil stabilization. Many studies of soil stabilization have been performed from past to present and behaviour of additives in soil stabilization were investigated. The aim of this study is to check usability of Green Bayburt Stone (GBS) wastes in soil stabilization. Bayburt Stone (BS) is used in mosques as a siding material, columns and different engineering structures as well as a decorative material. GBS is used in different industrial sectors. During mining and cutting process of these stones big amount of waste material occurs. The average rejecton rate is over $60 \%$ of GBS excavated from the bed. It causes severe environmental pollution.

Aftereffect of population and consumption growth, technological progress, industrialization and urbanization is adverse impact for human and environmental health [1]. Lime, cement and bitumen are commonly used additives in soil stabilization. Water content and load-bearing values are optimumised and plasticity is decreased with the addition of lime to natural soil [2]. Fly ash is another substantial additive for soil stabilization. Recent analyses show that rate of recycling of fly ash used for soil amendement is 95\% in Holland, Germany and Belgium, and nearly 50\% in England [3]. Reuse of waste materials for stabilization becomes recently compelling way of waste material utilization. Olive oil industry

*corresponding author; e-mail: fyilmaz@bayburt.edu.tr wastes [4], sewage sludge [5], waste heavy clay material from automotive industry and foundry sand blends from metallurgical industry [6] and cement kiln dust [7] were used as additive materials to improve mechanical strength of fine grained soils.

Kumar and Sharma [8] have showed that unconfined compressive strength of soil increases with the addition of fly ash. Ansary et al. [9] have proved that 12\%-18\% of fly ash and $3 \%$ of lime stabilization additives have fulfilled strength requirements of soil for pavement base and sub-base layers.

Lime stabilization is most common method to improve engineering properties of poor soils under railways, roads, parking, and building construction areas [10-12]. Ladd et al. [13] have proved that augmentation of unconfined compressive strength of lime treated soil persiste for over a decade. Eades and Grim [14] have showed that increasement in unconfined compressive strength of natural soil is $200 \%-1000 \%$ after lime contribution. Rajasekaran an Rao [15] pointed out that reasonable curing time of specimens for strength test is 30-45 days. After this time fuurther augmentation of strength can be negligible. Tonoz et al. [16] suggested that optimum lime addition to the soil is around $4 \%$ and curing period of samples is 28 days. Çalık and Şadoğlu [17] have showed that durability values of lime treated soil with pozzolanic additives was increased.

\section{Material and methods}

GBS was used in this study in the scope of waste material utilization. Although GBS possesses pozzolanic properties, it has not been so far used in soil stabilization in the region of Bayburt. Within the scope of the study 
lime and lime-GBS mixtures were used to improve the utilitary proprties of clayish subbase layers.

Prepared mixtures were compacted in standard proctor mould with optimum moisture content and standard proctor energy. After compaction, six samples were taken from the compacted soil with standard sampler due to determine approximate unconfined compressive strength. All the samples were cured in desiccators with $90 \%$ moisture content along 28 days. 3 samples from each components were used for freezing-thawing effect cycles. Period of performing of freezing-thawing cycles was 14 days.

After the Atterberg limit tests and sieve analysis, soil class is determined as $\mathrm{CH}$ according to the Unified Soil Classification System (USCS).

Optimum lime ratio of the soil was found $6 \%$ after $\mathrm{pH}$-meter test. Optimum lime ratio test results are illustrated in Fig. 1. Test samples were prepared with $6 \%$ of lime by adding $5 \%, 10 \%, 15 \%$ and $20 \%$ of GBS. Stabilization without lime is also examined in the scope of this study. Chemical and physical properties of GBS are given in Table I.

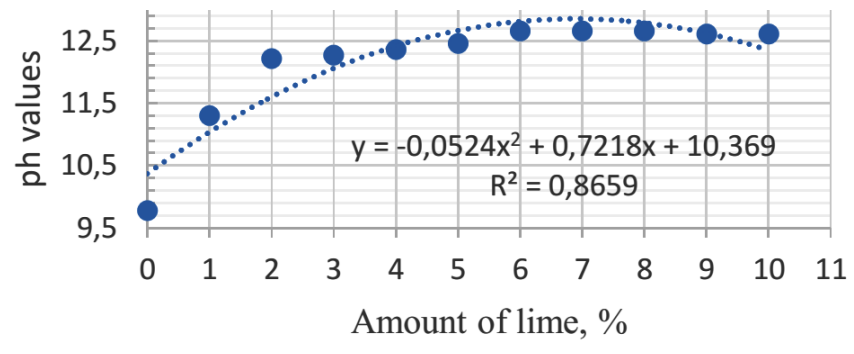

Fig. 1. Optimum lime ratio of the soil.

Chemical and physical properties of GBS.

\begin{tabular}{c|c|c|c|c|c|c|c|c|c|c|c|c}
\hline \hline $\begin{array}{c}\mathrm{SiO}_{2} \\
{[\%]}\end{array}$ & $\begin{array}{c}\mathrm{Al}_{2} \mathrm{O} 3 \\
{[\%]}\end{array}$ & $\begin{array}{c}\mathrm{Fe}_{2} \mathrm{O}_{3} \\
{[\%]}\end{array}$ & $\begin{array}{c}\mathrm{CaO} \\
{[\%]}\end{array}$ & $\begin{array}{c}\mathrm{MgO} \\
{[\%]}\end{array}$ & $\begin{array}{c}\mathrm{SO}_{3} \\
{[\%]}\end{array}$ & $\begin{array}{c}\mathrm{K}_{2} \mathrm{O} \\
{[\%]}\end{array}$ & $\begin{array}{c}\mathrm{Na}_{2} \mathrm{O} \\
{[\%]}\end{array}$ & $\begin{array}{c}\text { Loss of } \\
\text { ignition } \\
{[\%]}\end{array}$ & $\begin{array}{c}\mathrm{Cl} \\
{[\%]}\end{array}$ & $\begin{array}{c}\text { Specific } \\
\text { gravity } \\
{\left[\mathrm{g} / \mathrm{cm}^{3}\right]}\end{array}$ & $\begin{array}{c}\text { Blaine } \\
{\left[\mathrm{cm}^{2} / \mathrm{g}\right]}\end{array}$ & $\begin{array}{c}\text { Pozzolanic } \\
\text { activity }\end{array}$ \\
\hline 68.22 & 12.06 & 1.84 & 2.17 & 1.04 & 0.09 & 1.54 & 6.08 & 6.79 & 0.0281 & 2.30 & 6250 & 10.5 \\
\hline
\end{tabular}

From the XRD results of GBS, it was determined that clinoptilolite, heulandite, orthoclase, quartz are main minerals that BS contain. According to the laser particle sizer test results, it is determined that: grain size of the soil which passes through the sieve $200 \#$, changes between $0.05 \mu \mathrm{m}$ and $80 \mu \mathrm{m}$. Results of laser particle sizer and X-ray Diffraction (XRD) tests are shown in Fig. 2.

\section{Results and conclusion}

Unconfined compressive strength results of soil specimens are shown in Fig. 2 and Table II. With lime stabilization unconfined pressure strength of samples increased more than $1000 \%$. These are expected values in comparison of international literature search for lime stabilization. It was seen from the results that, generally with the addition of GBS to lime stabilized soil, unconfined pressure strength of samples get up to high values. It shows the pozzolanic activity of GBS as an expansive soil stabilizer. With the addition of GBS without lime, unconfined compressive strength of samples does not change in meaningful values.

Unconfined compressive strength of soil specimens decrease significantly after freezing-thawing cycles. For soil + GBS samples those changes are negligible in respect to natural soil properties. It demonstrates the usefulness of these stone wastes for eliminating of freezing- thawing effect in soil stabilization. As a consequence, results show that waste GBS with lime can be used for soil stabilization. Method will be environmentally friendly practice.

TABLE II

Unconfined compressive strength values of test specimens.

\begin{tabular}{c|c|c}
\hline \hline Test specimens & $\begin{array}{c}\text { unconfined } \\
\text { compressive } \\
\text { strength } \\
{[\mathrm{kPa}]}\end{array}$ & $\begin{array}{c}\text { unconfined } \\
\text { compressive } \\
\text { strength after } \\
\text { freezing-thawing } \\
\text { effect }[\mathrm{kPa}]\end{array}$ \\
\hline soil & 118.46 & 88.77 \\
soil $+5 \%$ GBS & 115 & 94.25 \\
soil $+15 \%$ GBS & 123.04 & 96.84 \\
soil $+20 \%$ GBS & 119.33 & 96.91 \\
soil $+6 \%$ lime & 121.49 & 97.05 \\
soil $+6 \%$ lime $+5 \%$ GBS & 1540.29 & 675.42 \\
soil $+6 \%$ lime $+10 \%$ GBS & 1463.93 & 1380.49 \\
soil $+6 \%$ lime $+15 \%$ GBS & 1472.84 & 1372.48 \\
soil $+6 \%$ lime $+20 \%$ GBS & 1363.02 & 1270.76
\end{tabular}




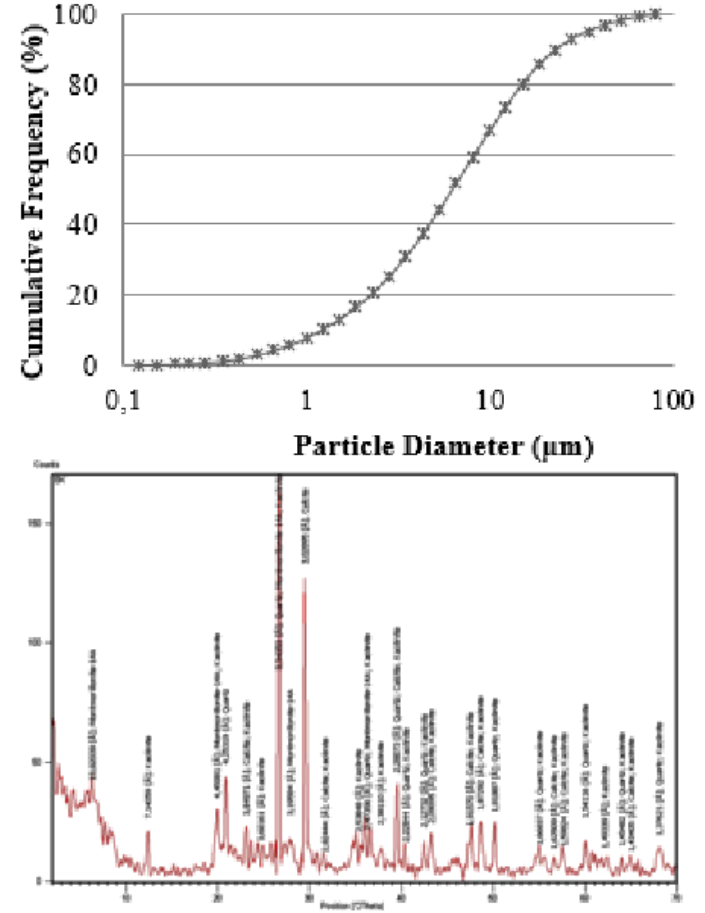

Fig. 2. Particle sizer test and XRD results of tested soil.
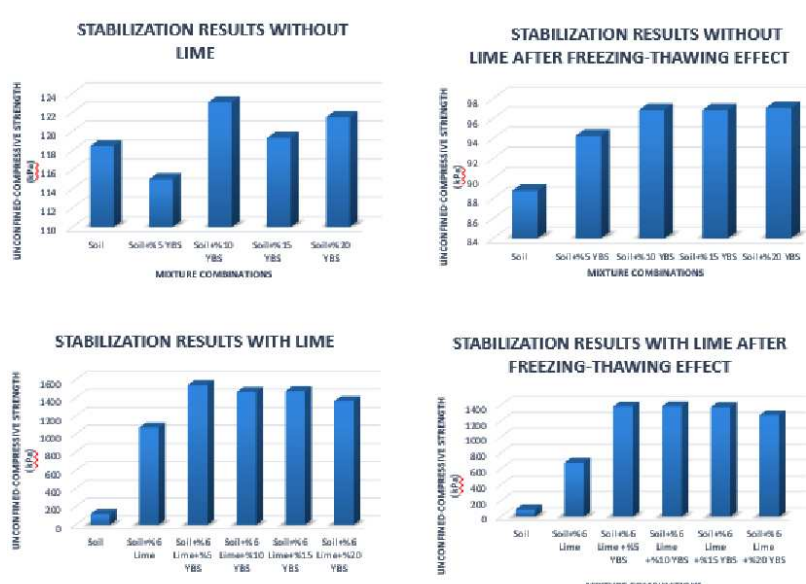

STABILIZATION RESULIS WITH LIME AFTER FREEING-THAWING EFECT

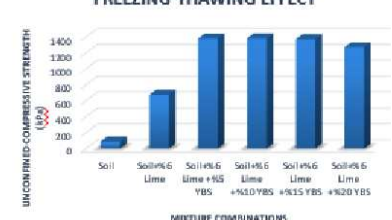

Fig. 3. Unconfined compressive strength of test specimens.

\section{References}

[1] H. Palabıyık, D. Altunbaş, Kentsel KatıAtıklar ve Yönetimi, Çevre Sorunlarına Çağdaş Yaklaşımlar: Ekolojik, Ekonomik, Politik ve Yönetsel Perspektifler, Ed. C. Marin, Beta, İstanbul, (2004), p. 103, (in Turkish).

[2] A. Kavak, Ph.D. Thesis, University of Boğaziçi, İstanbul 1996, (in Turkish).

[3] U. Bhattachariee, T.C. Kandpal, Energy 27, 151 (2002).

[4] M.F. Attom, M.M. Al-Sharif, Appl. Clay Sci. 113, 219 (1998).

[5] L.C.F.L. Lucena, J.F.T. Juca, J.B. Soares, M.G. Portela, J. Mater. Civil Eng. 26, 04014051 (2014).

[6] Q. Dong, V. Huang. B. Huang, J. Mater. Civil Eng. 26, 04014065 (2014).

[7] G. Miller, S. Azad, J. Constr. Build Mater. 14, 89 (2000).

[8] B.P. Kumar, R.S. Sharma, J. Geotech. Geoenviron. 130, 764 (2004).

[9] M.A. Ansary, M. Noor, M. Islam, Effect of Fly Ash Stabilization on Geotechnical Properties of Chittagong Coastal Soil Geotechnical Symposium, Roma 2006, p. 443.

[10] M. Al-Mukhtar, A. Lasledj, J.F. Alcover, Appl. Clay Sci. 50, 199 (2010).

[11] I. Goldberg, A. Klein, ASTM Special Publication, Symp. on Exchange Phenomenon in Soils142, 53 (1952).

[12] K.E. Clare, A.E. Crunchley, Geotechnique 5, 97 (1957).

[14] R.L. Terrel, A. Epps, J.E. Barenberg, J.K. Mitchell, M.R. Thompson, Soil stabilization, FHWA, US. Department of Transportation, Washington DC 1979.

[13] C.C. Ladd, Z.C. Moh, T.W. Lambe, Bull. Highw. Res. , 64 (1960).

[14] J.L. Eades, R.E. Grim, Bull. Highw. Res. Board 139, 61 (1966).

[15] G. Rajasekaran, S.N. Rao, Ocean Engineering 29, 113 (2002).

[16] M.C. Tonoz, R. Ulusay, C. Gökçeoğlu, Earth Environ. Sci., LNES 104, 466 (2004).

[17] U. Çalik, E. Sadoglu, Natural Hazards 71, 1289 (2014). 